\title{
Geology of the Area
}

Adjacent to the

Free Enterprise Mine

Jefferson County

Montana

GEOLOGICAL SURVEY BULLETIN 988-G

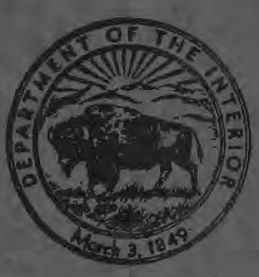




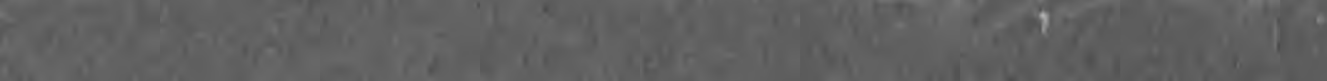
6.6.

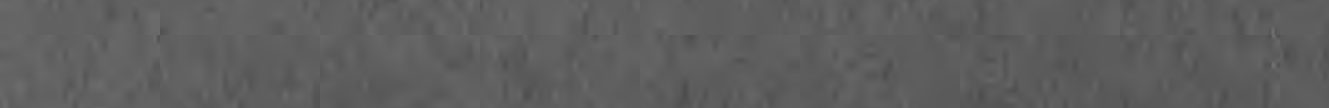

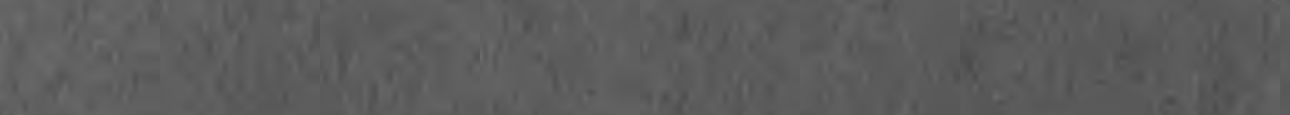

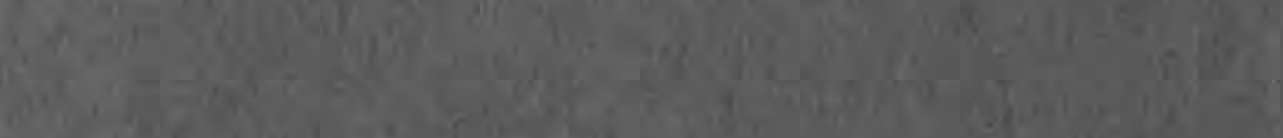

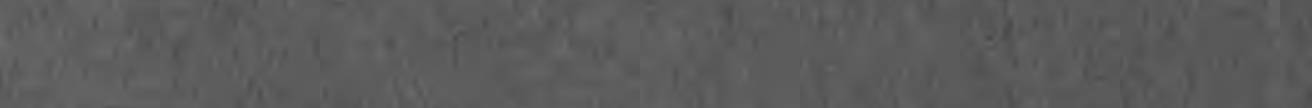
$(6,1)$

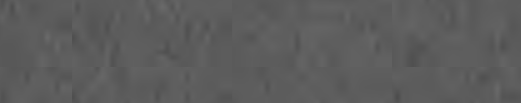

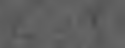
nive

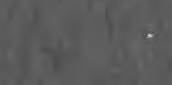
(6.)

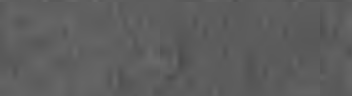

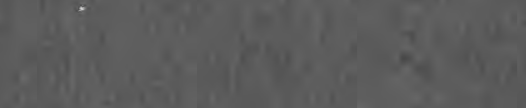
$4^{3} 1$
$13^{2} 3$

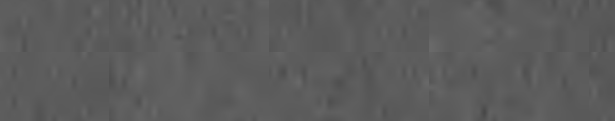

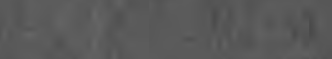
$401+2=$
(i.

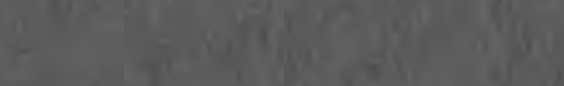
tion:

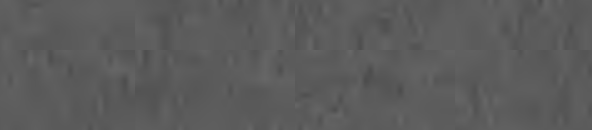

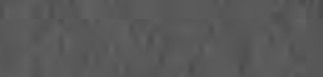
is
i1.

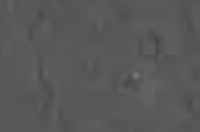

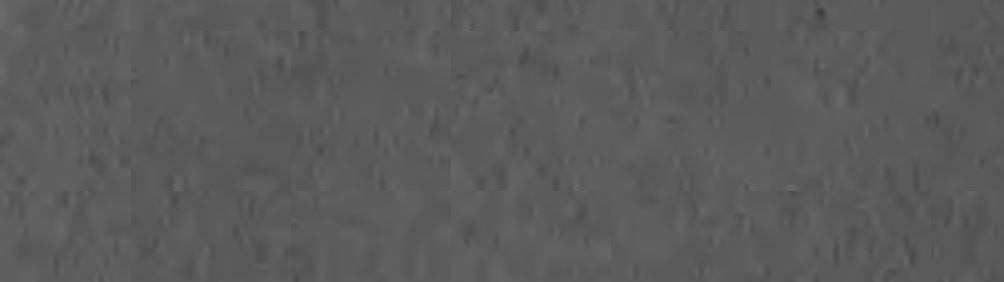

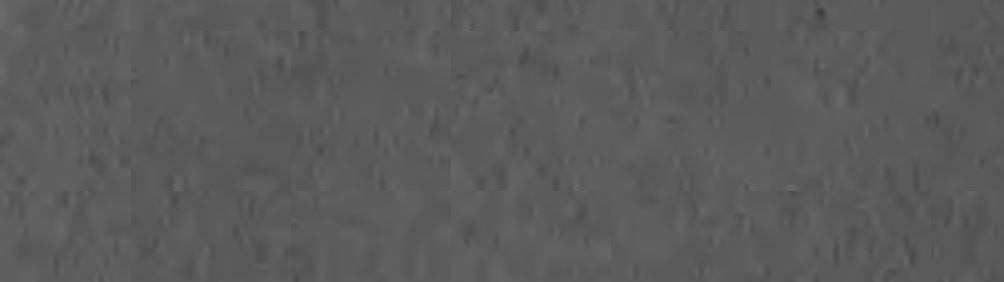

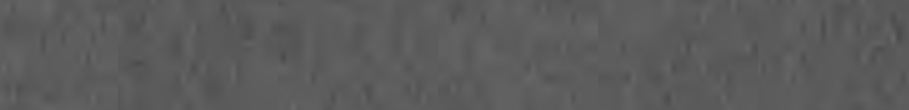

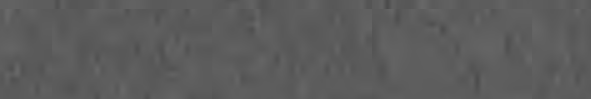

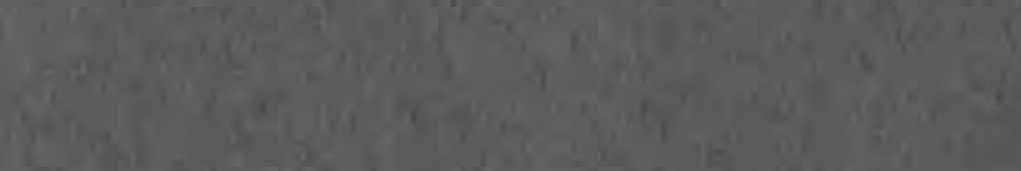

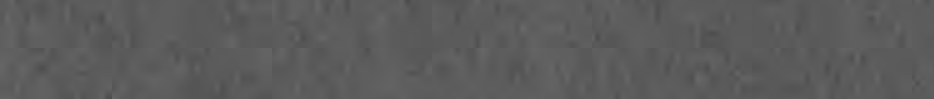

6. $+2 \times 1$

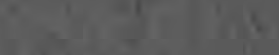

$x^{2}+x^{2}+y^{2}+y^{2}$

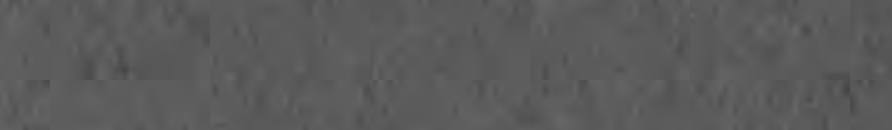

18

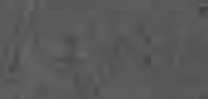

(1)

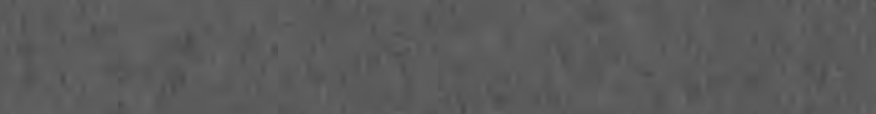

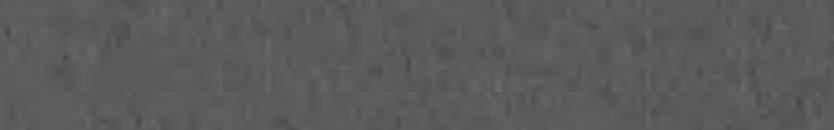

eiclan

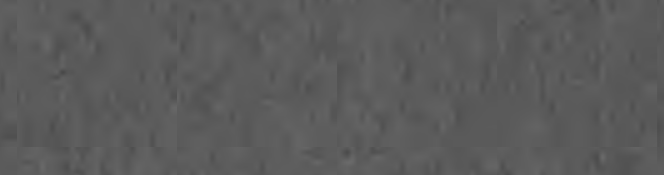

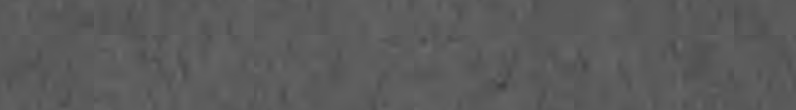

yex

s

an's. Cr Tr

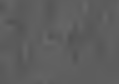




\section{Geology of the Area}

Adjacent to the

Free Enterprise Mine

Jefferson County

Montana

By W. A. ROBERTS and A. J. GUDE 3d

A CONTRIBUTION TO THE GEOLOGY OF URANIUM

GE OLOG ICAL S URVEY B ULLETIN 988-G

This report concerns work done on behalf of the U.S. Atomic Energy Commission and is published with the permission of the Commission

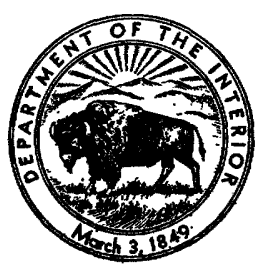




\section{UNITED STATES DEPARTMENT OF THE INTERIOR}

Douglas McKay, Secretary

GEOLOGICAL SURVEY

W. E. Wrather, Director

For sale by the Superintendent of Documents, U. S. Government Printing Office Washington 25, D. C. 


\section{CONTENTS}

\begin{tabular}{|c|c|}
\hline & Page \\
\hline Abstract & 143 \\
\hline Introduction & 143 \\
\hline Purpose, location, and accessibility & 143 \\
\hline Previous work & 145 \\
\hline Field work & 145 \\
\hline Radiometric survey & 145 \\
\hline Geologic studies & 145 \\
\hline Acknowledgments & 147 \\
\hline 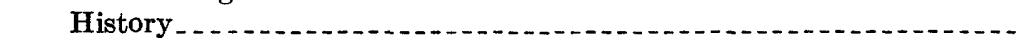 & 147 \\
\hline Genlogy & 148 \\
\hline General features. & 148 \\
\hline Igneous rocks $\ldots \ldots \ldots \ldots$ & 148 \\
\hline Quartz monzonite. & 148 \\
\hline 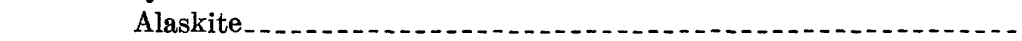 & 149 \\
\hline Dacite(?) & 150 \\
\hline Silicification & 150 \\
\hline Structure & 151 \\
\hline Mineral depositss & 151 \\
\hline General geologic features & 151 \\
\hline Mineralogy & 152 \\
\hline General character and classification & 152 \\
\hline Alteration by meteoric solutions & 153 \\
\hline Suggestions for prospecting & 153 \\
\hline Literature cited & 154 \\
\hline Index & 155 \\
\hline
\end{tabular}

\section{ILLUSTRATIONS}

Prate 22. Preliminary map showing geology of Free Enterprise mine and vicinity, T. 6 N., R. 4 W......... In pocket

23. Detailed map of the mine and vicinity ............. In pocket

24. Geologic traverse along unnamed gully, northeast of mine, secs. 18,19 , and 20 In pocket

FIgure 37. Index map of Free Enterprise mine and vicinity, Jefferson

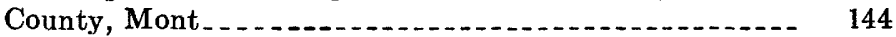

38. Map showing radioactivitv anomalies $\ldots \ldots \ldots \ldots$

III 



\title{
A CONTRIBUTION TO THE GEOLOGY OF URANIUM
}

\author{
GEOLOGY OF THE AREA ADJAGENT TO THE FREE \\ ENTERPRISE MINE, JEFFERSON GOUNTY, MONTANA
}

\author{
By W. A. Roberts and A. J. Gude 3d
}

\begin{abstract}
Uranium minerals occur in a silver-bearing, cryptocrystalline silica vein deposit that cuts quartz monzonite and alaskite at the Free Enterprise mine, 2 miles west of Boulder, Mont. The Free Enterprise vein is one of many silicified reeflike structures in this area, most of which trend about $\mathbf{N} .60^{\circ} \mathbf{E}$.

The cryptocrystalline silica veins commonly occur in groups having a lenticular pattern. Where quartz monzonite is the wall rock, they are bordered by an altered zone, but no alteration was noticed where alaskite is adjacent to the silica veins. These groups of silica veins and the enclosing altered country rock are called silicified zones in this report. No uranium minerals were observed at the surface, but radioactivity anomalies were noted at 57 outcrops. Leaching by downward percolating waters has removed most of the uranium from the near-surface part of the Free Enterprise vein and probably has slightly enriched parts of it and the adjacent wall rock from the bottom of the leached zone to the ground-water level.

The quartz monzonite appears to be a more favorable host rock for this eryptocrystalline silica veins and associated uranium minerals than the alaskite.

Alaskite occurs as vertical dikes and plug-like masses and as irregularly shaped, gently dipping masses. The smaller bodies probably were introduced into open fractures formed during the cooling of the quartz monzonite.

The nature of the Free Enterprise deposit, the abundance of silicified veins, and the weak to moderate surficial radioactivity of some of these veins suggest that many small deposits of uranium and silver minerals may occur in this area in significant concentrations at relatively shallow depth. Cost of exploring and mining, however, might be prohibitive.
\end{abstract}

\section{INTRODUCTION}

\section{PURPOSE, LOCATION, AND ACCESSIBILITY}

Uranium minerals occur in a silver-bearing cryptocrystalline silica vein at the Free Enterprise mine in the Boulder mining district, Montana. The area around this deposit was studied to determine the origin and the mode and extent of occurrence of the uranium minerals. This work is part of a general study of uranium deposits 
being done by the U. S. Geological Survey on behalf of the Division of Raw Materials of the U. S. Atomic Energy Commission.

The Free Enterprise mine is in sec. 19, T. 6 N., R. 4 W., about 2 miles west of Boulder, Jefferson County, Mont. (fig. 37) and 400 feet south of the graded road between Boulder and Comet. Boulder railroad station, on a branch of the Great Northern Railroad, is on the road to Comet about ha.fway between the town of Boulder and the Free Enterprise mine.

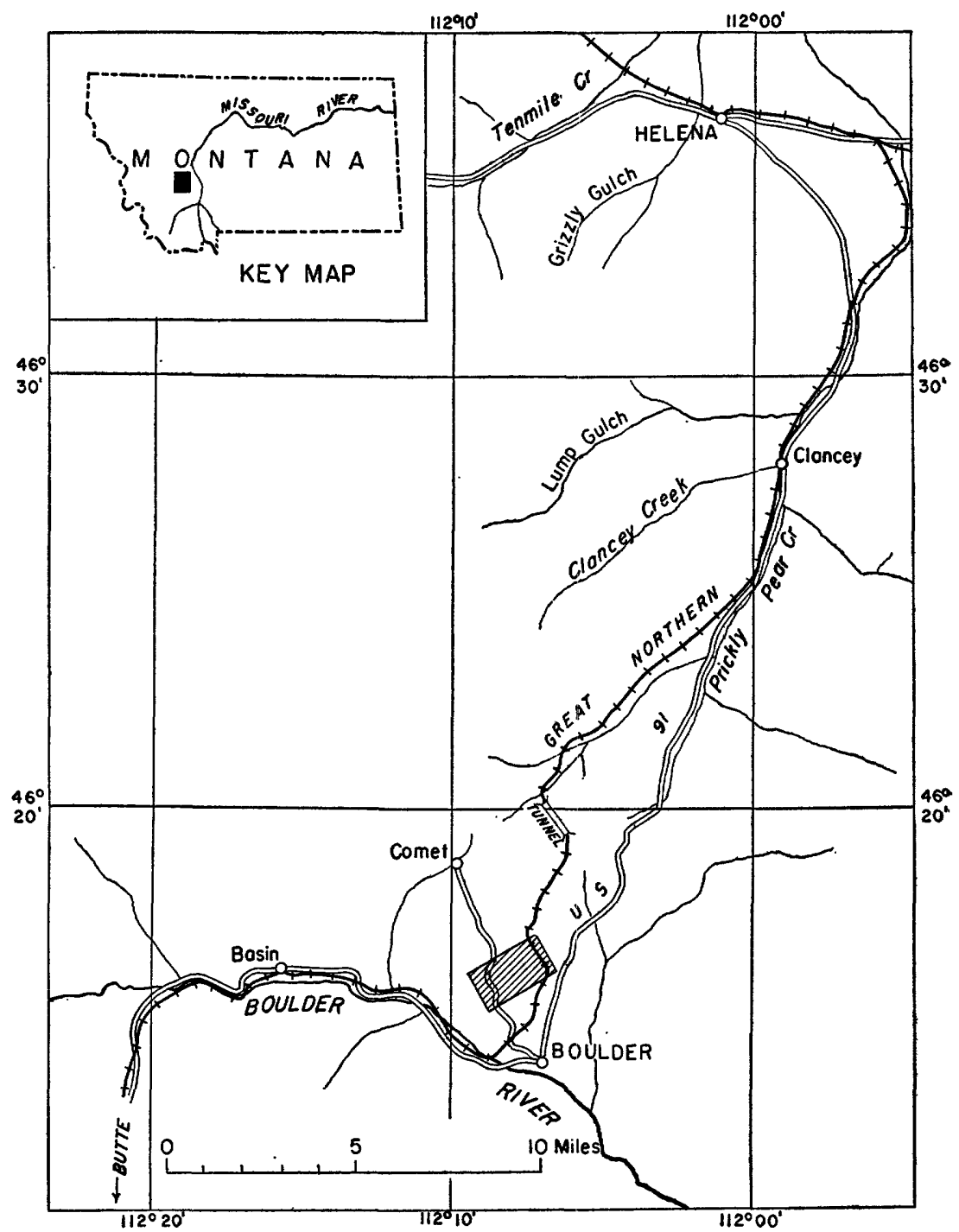

FiguRe 37.-Index map of Free Enterprise mine and vicinity, Jefferson County, Mont. 
Relief in the vicinity of the mine ranges from 100 to 300 feet between the ridges and intervening gully bottoms. The Boulder River, a tributary of the Jefferson River, is the nearest perennial stream and is about 2 miles south of the Free Enterprise mine. Although the winter climate is severe, the mine is favorably located and should be able to operate throughout the year.

\section{PREVIOUS WORK}

Previous reconnaissance geologic work in the Boulder batholith and the Boulder mining district was done by Knopf (1913), Pardee and Schrader (1933), and Billingsley $(1916,1918)$. In 1950 Thurlow and Reyner made a detailed study of the uranium deposit in the Free Enterprise mine for the Atomic Energy Commission. Their findings are described in two unpublished reports. ${ }^{1}$ Uranium-bearing deposits, similar to those of the Free Enterprise vein, occur near Clancey, 15 miles north of Boulder; these deposits were studied by the writers during 1950 and have been described in a previous report (Roberts and Gude, 1953).

\section{FIELD WORK}

\section{RADIOMETRIC SURVEY}

A radiometric survey of the Free Enterprise mine and vicinity (fig. 38) was made with a portable Geiger counter using six 14-inch gamma tubes connected in parallel as a probe. All major outcrops and most of the intervening mantle were traversed and measured with the counter. The lowest meter reading observed was 6.5 on the 2.0 scale and is designated as background for this area. The only high-intensity radioactivity detected was at the mine, where mineralized rock from the underground workings was on the dump and in ore piles. No anomalies were detected at exposures of the Free Enterprise vein at the surface.

There were 54 low-intensity anomalies (10-15 on the 2.0 scale) observed in this area. In addition to these, three anomalies between 15.0 on the 2.0 scale and 5.0 on the 20.0 scale were detected (fig. 38).

\section{GEOLOGIC STUDIES}

Geologic field work was begun September 26, 1950, and was completed October 17, 1950. The geology of an area about 2 square miles extending northeast from the Free Enterprise mine was

\footnotetext{
1 'Thurlow, E. E., and Reyner, M. L., Free Enterprise uraninm prospect, Jefferson County, Mont. : Atomic Energy Commission RMO 678, 1950; Reyner, M. L., Reconnaissance of Basin-Fioulder-Clancey area, Jefferson County, Mont. : Atomic Energy Commission, RMo 674, 1950. [Manuscript reports in files of Atomic Energy Commission.]
} 


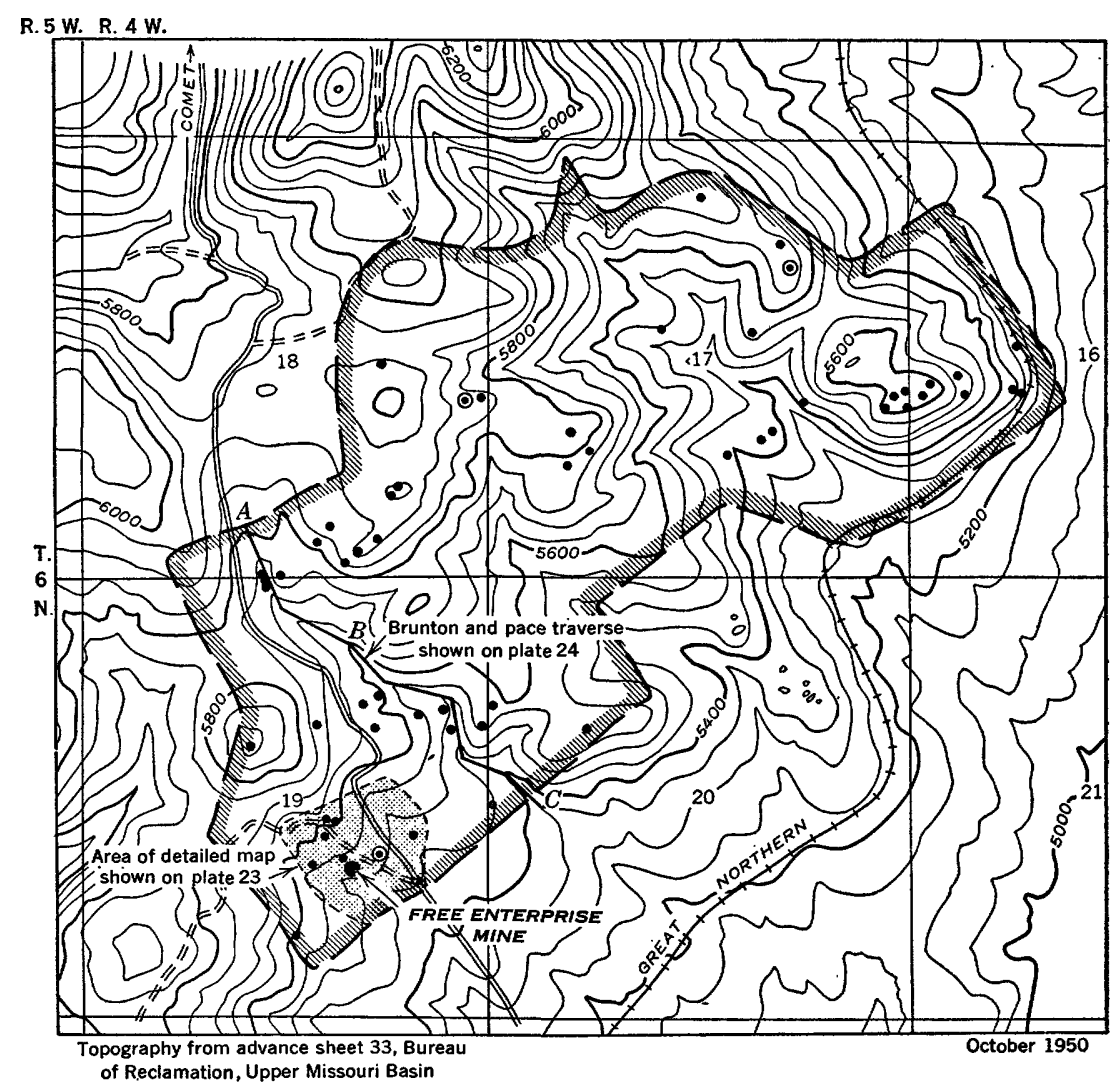
of Reclamation, Upper Missouri Basin

EXPLANATION

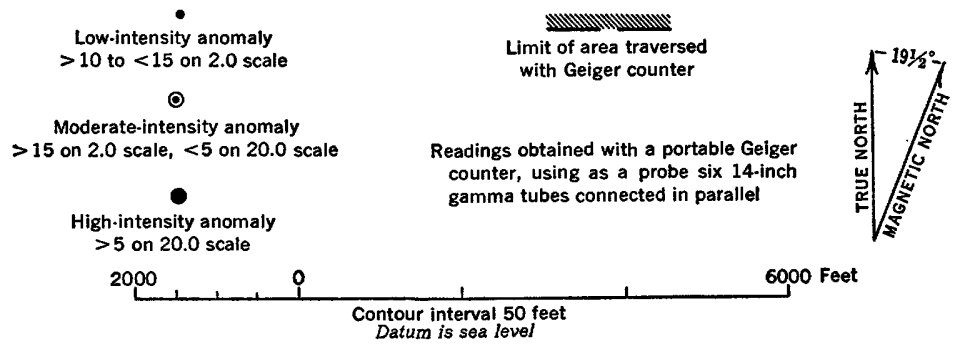

FiaUn 38,-Map showing radioactivity anomalies of the Free Fnterprise mine and vicinity.

mapped at a scale of 1:12,000 (pl. 22). The geology of the area around the mine shaft was mapped in detail by plane-table methods (pl. 23), and a Brunton and pace traverse was made of the first gully north of the mine shaft (pl. 24). The geology of the underground workings at the mine had been mapped previously by geologists of the U. S. Atomic Energy Commission and was not remapped by the writers. 


\section{ACKNOWLEDGMENTS}

Valuable help and suggestions were given to the writers by $\mathbf{M}$. $\mathbf{R}$. Klepper of the Geological Survey. Cordial cooperation was extended by Wade V. Lewis, president of the Elkhorn Mining Co., and operator of the Free Enterprise mine.

A. F. Trites, Jr., of the Geological Survey, established triangulation stations in this area which were used as control points in mapping the areal geology, and J. W. Hosterman, of the Geological Survey, assisted in making the detailed map of the area around the mine shaft.

\section{HISTORY}

Gold, silver, and base metals were discovered in the Boulder district before 1870 and have been mined intermittently from different deposits since that time. Pardee and Schrader (1933, p. 286) do not separate completely the Boulder and the Basin mining districts but list the value of minerals produced from the Boulder district from 1904 to 1928 as $\$ 325,000$. The minerals mined during this period presumably contained lead, zinc, gold, silver, and copper. Although the exact records are not available, the value of metal production from 1928 to 1936 was probably very small. The value of gold, silver, lead, copper, and zinc produced from 1937 to 1948 was about $\$ 56,000$.

About April 1949 Sanford Davis of Boulder recognized uranium minerals on the dump of the old Silver Bell prospect. Mr. Davis, Edward C. Miles of Helena, and Wade V. Lewis of Boulder visited the property later with a Geiger counter and detected radioactivity at the dump.

Messrs. Davis, Miles, and Lewis now own the 29 unpatented claims of the Free Enterprise-Boulder Mercury group and have renamed the Silver Bell prospect the Free Enterprise mine. The property was leased to the Elkhorn Mining Co. of Boulder, Mont. This company in turn negotiated an operating agreement with the Sunshine Mining Co. of Coeur d'Alene, Idaho, who restored and extended the old workings in late 1949 and early 1950. When the Sunshine Mining Co. withdrew, the Elkhorn Mining Co. began mining on the 80foot level and has since shipped a few tons of relatively high grade uranium-silver ore and three carloads of low-grade uranium ore to the Vitro Chemical Co. in Salt Lake City, Utah. The production to January 25, 1952, is shown in the following tabulation:

\begin{tabular}{|c|c|c|c|}
\hline Dry pounds & Dry tons & $\begin{array}{c}\mathrm{U}_{3} \mathrm{O}_{\mathbf{2}} \\
\text { (percent) }\end{array}$ & $\underset{(\text { oz/ton) }}{A g}$ \\
\hline 2245 & 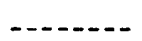 & 1. 34 & 68. 25 \\
\hline 2617 & $\ldots-\ldots$ & 1. 61 & 133. 5 \\
\hline 3788 & - n- & .60 & 5. 55 \\
\hline 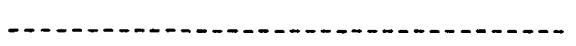 & 43. 145 & .16 & - \\
\hline 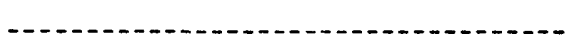 & 49. 885 & .15 & - - \\
\hline r & 55. 872 & .14 & --n-n-n- \\
\hline
\end{tabular}




\section{GEOLOGY}

\section{GENERAI FEATURES}

The Free Enterprise mine and the area mapped around the mine (pl. 22) are entirely within the Boulder batholith, a large intrusive body composed chiefly of quartz monzonite. The quartz monzonite is cut by plugs and dikes of alaskite and dacite(?). Many of the alaskite dikes are gently dipping, irregularly shaped, lens-like bodies that crop out over areas that are relatively large compared with the thickness of the bodies involved.

Batholithic rocks have been fractured, sheared, and brecciated along narrow zones that trend about N. $60^{\circ} \mathrm{E}$. and generally dip steeply to the northwest. Some of these zones were later altered and silicified and contain, in addition to the altered country rock, numerous short lentil-like veins of cryptocrystalline silica. Some zones have been recurrently silicified and brecciated. The topographic expressions of these silicified zones have been called reefs because they typically stand above the adjacent ground surface. Small, high-angle faults trending northwest offset the silicified zones as much as several hundred feet.

The only sedimentary rocks in the area mapped are Recent deposits of alluvial and colluvial material. Small terraces occur in the gullies several feet above the present bottoms. A thin veneer of slope wash and mantle blankets most of the area. The alluvial gully fills and terraces are too small to map at a scale of 1:12,000 (pl. 22).

\section{IGNEOUS ROCKS}

\section{QUARTZ MONZONITE}

The principal rock type of the Boulder batholith has been described by Knopf (1913, p. 10) and by Pardee and Schrader (1933, p. 3) as quartz monzonite. This quartz monzonite is a light-gray mediumgrained equigranular rock that consists, in order of decreasing abundance, of plagioclase, quartz, orthoclase, biotite, and hornblende. Orthoclase occurs as large scattered pink phenocrysts about 1 inch long. Typically, the rock weathers into large rounded boulders and finer grained detritus that is granular and iron-stained and contains conspicuous biotite.

Wherever a silica vein cuts quartz monzonite an altered zone occurs on both sides of the vein; however, altered zones are present that are not cut by visible silica veins. The altered facies differ from the unaltered quartz monzonite in the following ways: The altered facies appear to be slightly finer grained; ferromagnesian minerals are sparser, although biotite occurs locally as scattered flakes; there 
appears to be more orthoclase; and clay minerals have replaced some of the feldspars. Locally sericite occurs in the zone of alteration adjacent to silica veins, especially in the northwestern part of the area mapped, but the relative ages of the sericite and the silica are not known. Contacts between the unaltered and altered country rock are gradational through an interval ranging from 1 inch to about 1 foot. The altered facies generally weather to angular blocks instead of the rounded boulders and granular detritus formed by the weathering of the unaltered quartz monzonite.

\section{ALASKITE}

Alaskite dikes and plug-like masses cut the quartz monzonite and probably occupy tension fractures formed during the cooling of batholithic quartz monzonite. Many of these dikes are gently dipping irregular-shaped, lenticular sheet-like masses that crop out over areas as much as a quarter of a square mile. Some of the dikes have a vertical or steep dip. The alaskite commonly weathers into blocks and decomposes to a soil that is relatively free from biotite.

The alaskite is composed essentially of quartz and potash feldspar with subordinate amounts of plagioclase and rare amounts of biotite. Mineralogically, it is similar to the alaskite bodies near Clancey, Mont., but texturally the alaskites of these two areas differ significantly. In the Free Enterprise area the principal variety of alaskite has both saccharoidal and granitic textures in different grain sizes ranging from about 0.1 millimeter to 4 millimeters; however, the bulk of the rock is a medium-grained alaskitic granite with a grain size of 1 to 2 millimeters. The distinctly porphyritic facies that is common near Clancey was not seen in the Free Enterprise area, and the pegmatitic facies is rare and probably comprises less than 1 percent of all alaskite outcrops.

The contacts between the alaskite and the quartz monzonite are sharp. Although locally the grain size of the alaskite is slightly finer at the borders of a body, chilled selvages of alaskite have not been found. This suggests that the alaskite was emplaced in fractures that formed while the quartz monzonite was still cooling. The alaskite is probably derived from a quartz- and potash-rich magmatic residuum of the main batholithic mass.

A large body of relatively quartz-poor alaskite or leucogranite that apparently contains an appreciable amount of plagioclase, as well as abundant orthoclase, is exposed in a railroad cut in the southeastern part of the area mapped (pl. 22). Black tourmaline rosettes occur in the alaskite about 4 feet above the railroad bed for 20 to 30 feet along the northwestern side of the cut. For purposes of mapping, this rock type was not distinguished from the plagioclase-poor alaskite. 
Cryptocrystalline silica veins and stringers cut both the alaskite and the quartz monzonite, but no zones of alteration were seen along: the borders of the veins in the alaskite. Locally, however, sericitehas been recognized in alaskite adjacent to silica veins.

\section{DACTTE(?)}

One small aphanitic dike of dacite(?) cuts quartz monzonite at the eastern edge of the area shown in plate 23 . The relative ages of the dacite (?) and the alaskite could not be determined in this area, but studies in nearby areas indicate that the dacite(?) is younger.

\section{SILICIFICATION}

Within the area mapped both the quartz monzonite and alaskite are cut by many zones composed in part of groups of stringers and veins of cryptocrystalline silica. These silica veins are each within: a zone of fracturing and alteration in quartz monzonite or within ar zone of fracturing without recognizable alteration in alaskite. Most silicified zones are somewhat lenticular, and generally the stringers. and veins of silica within them are arranged in a subparallel to en: echelon arrangement. The stringers and veins are roughly parallel to the elongation of the zones. The silicified zones, which includethe silica veins and stringers, range in thickness from a few inches to several tens of feet.

Contacts of the cryptocrystalline silica veins and stringers with both the quartz monzonite and alaskite are sharp; however, disseminated cryptocrystalline silica has altered and partially replaced thewall rock of the quartz monzonite from a fraction of an inch to several feet adjacent to the veins. Locally, closely spaced iron-stained joints occur in the marginal parts of the silicified zones and in the adjacent country rock. Brecciated vein fragments cemented by silica, and fracture-fillings of brown opaline silica are common in the veins, indicating that there werp at least two depositional stages of hydrothermal or primary silicification, and one stage of secondary. silicification.

The silicified zones or reefs weather less rapidly than either the quartz monzonite or the alaskite and typically occur as ribs or low ridges that stand from 6 inches to 20 feet above the surrounding: surface.

The quartz monzonite was the more favorable host rock for the silica and apparently was more fractured and thus more permeable than the alaskite. Silica veins that cut both quartz monzonite and alaskite are generally thicker and more continuous in the quartz monzonite. This observation also has been made in the Free Enterprise mine. ${ }^{2}$

Thurlow, F. F., and Reyner, M. L., op. cit. 


\section{STRUCTURE}

The many steeply-dipping silicified zones have a general trend of about N. $60^{\circ}$ E. and dip northwestward. They are the most striking structural features in the Free Enterprise area. Many of these silicified veins are brecciated, and gouge or microbreccia is found at the margins or within some of them.

The veins are offset as much as several hundred feet (pl. 22) by high-angle northwest-trending cross faults. These are probably normal faults along which, in most cases, the northeastern blocks moved down. Faults in the batholithic rocks are difficult to detect-the lack of key units for correlation obscures all but the most obvious ones.

The principal gullies and intervening ridges are transverse to the veins and are roughly parallel to the northwest-trending normal faults.

\section{MINERAL DEPOSITS}

\section{GENERAL GEOLOGIC FEATURES}

The only known occurrence of uranium minerals in this area is at the Free Enterprise mine. Although no uranium minerals were seen in surface outcrops, low-intensity radioactivity anomalies on veins in the area suggest that uranium may occur beneath the surface in many of them.

Uranium occurs as a primary constituent of a silicified vein on the 80-foot level of the Free Enterprise mine. Most of the primary uranium minerals on the 80 -foot level have been weathered to secondary gummite-type uranium minerals. Metatorbernite and autunite occur disseminated in the wall rock adjacent to the vein at the 80-footlevel.

A series of 12 or more nearly parallel silicified zones, one of which includes the Free Enterprise vein, crop out in the area mapped (pl. 23). They have an average strike of about N. $60^{\circ} \mathrm{E}$. and a dip of $85^{\circ}$ NW. These zones cut the quartz monzonite and both the vertical and the gently dipping alaskite dikes. Several gently dipping alaskite sheet-like masses crop out near the mine shaft, and at least two of these have been exposed by the underground workings. ${ }^{3}$ The steeply dipping alaskite dike that crops out about 100 feet west of the shaft is offset slightly by the Free Enterprise vein indicating that some movement has occurred along this vein. Underground studies by Thurlow and Reyner ${ }^{4}$ indicate that this dike may be connected with the alaskite body that crops out about 130 feet east of the shaft by a gently dipping alaskite mass exposed in the mine workings (pl. 23, section $\mathbf{B B}^{\prime}$ ). A dacite(?) dike 25 feet thick shown in the southeastern part of the detailed map strikes roughly parallel to the silicified zones.

'Thurlow, E. E., and Reyner, M. L., op. cit.

¿ Thurlow, E. E., and Reyner, M. L., op. eit. 
Intense weathering has left only short discontinuous outcrops of the silicified zones, commonly less than 10 feet long, in the vicinity of the Free Enterprise shaft. In mapping, these zones were carefully projected (pl.23) ; however, only exploration such as bulldozing, drilling, or driving of underground workings can determine their extent and continuity.

\section{MINERALOGY}

Scattered crystals of pyrite are found in most of the silica veins at the surface. At the Free Enterprise mine small amounts of pyrite, galena, ruby silver, argentite, native silver, molybdenite, chalcopyrite, arsenopyrite, and barite have been found in the vein. ${ }^{5}$ The uranium minerals present are uraninite, gummite-type hydrous oxides, autunite, metatorbernite, and some zeunerite and uranophane. ${ }^{8}$ Autunite and metatorbernite occur both along fractures in and adjacent to the vein and disseminated in the wall rock as much as 2 feet from the vein. A dark-brown primary uranium mineral resembling samarskite, but as yet unidentified, was found at the southeast end of the drift on the 80-foot level.

Wade V. Lewis (oral communication) reported that cinnabar was collected from a prospect pit on a cryptocrystalline silica vein about 1,500 feet north of the Free Enterprise shaft. Although a search was made, no cinnabar was found by the writers. Cinnabar is also reported by Larsen (1917) to occur in a cryptocrystalline silica vein about half a mile north of Boulder station and about 100 yards west of the railroad tracks. This locality is 1,500 to 2,000 feet east of the mapped area (pl.22).

\section{GENERAL CHARACTER AND CLASSIFICATION}

Uranium minerals occur at the Free Enterprise mine in and adjacent to a vein-type deposit of cryptocrystalline silica in fractures in the batholithic rock. The primary minerals occur as pods in the vein, and the secondary minerals occur as fracture linings and as scattered crystals in and adjacent to the vein. The Free Enterprise vein is one of many silicified and altered zones that occur in this area (pl. 22), but it is the only one in which uranium minerals have been found, although a number of others show weak to moderate radioactivity anomalies.

Although the zones of alteration and probably the fractures in which the silica veins have been deposited are traceable for hundreds to thousands of feet, the actual veins and stringers of cryptocrystalline silica characteristically swell and pinch out over distances of several

5 Thurlow, E. E., and Reyner, M. L., op. cit.

- Thurlow, E. E., and Reyner, M. L., op. cit. 
feet to several hundred feet. Altered zones border the silica veins in the quartz monzonite country rock and may extend beyond the visible silica stringers and veins. Disseminated cryptocrystalline silica probably has impregnated most of the rock in the altered zones but is most noticable adjacent to the silica veins.

Thurlow and Reyner ${ }^{7}$ have classified the vein as a mesothermal fissure filling on the basis of the mineralogic assemblage. The writers feel, however, that the mass of brecciated cryptocrystalline silica, the reported occurrence of cinnabar at two localities, one about 1,500 feet north and the other about half a mile east of the Free Enterprise shaft in veins similar. to the Free Enterprise vein, and the occurrence of argentite and primary ruby silver indicate that this deposit and all other cryptocrystalline silica veins in the area are probably epithermal. This deposit probably is genetically related to the batholithic mass.

\section{ALTERATION BY METEORIC SOLUTIONS}

By the process of weathering, the primary minerals in the Free Enterprise vein have been converted to hydrous oxides, silicates, and uranyl phosphates. The phosphates, autunite and metatorbernite, are the most widespread of the secondary uranium minerals. They occur as fracture- and cavity-fillings in the wall rock. This indicates some depletion of parts of the primary uranium deposit. The gummite-type secondary uranium minerals are typical within or very near the vein; most of them apparently were formed in place.

Thurlow and Reyner" state "Extensive near-surface leaching coupled with selective precipitation along favorable zones within and adjacent to the vein have combined to form enriched pockets of secondary uranium minerals These zones may be related to the former water level $* * *$ They report that below the water level on the 140-foot level the radioactivity is slight and that only minor amounts of secondary uranium minerals are found in vugs and on fracture surfaces.

\section{SUGGESTIONS FOR PROSPECTING}

The present study has revealed several guides that may be useful to the prospector. Radioactivity, which may indicate the presence of uranium, is associated principally with silica veins that crop out as reefs, most of which stand 6 inches to 20 feet above the surrounding surface. Studies at the Free Enterprise mine show that leaching by downward percolating water has removed most of the uranium from the near-surface silicified zones; accordingly, a radiation detector must be used in this area for efficient prospecting, but this may fail to

7 Thurlow, E. E., and Reyner, M. L., op. cit. 
give reliable results if thorough leaching of uranium has extended downward a foot or more. Quartz monzonite country rock appears to have been a more favorable host rock than alaskite for the silicified zones and associated uranium minerals. No abnormal radioactivity has been detected in any of the dacite(?) dikes tested in either the Boulder area or in the Clancey area to the north.

Suggestions for prospecting in the Clancey area probably are useful to the prospector not only near Boulder and Clancey but in the Boulder batholith as a whole (Roberts and Gude, 1953, pp. 84-85). Intersections of small spurlike reefs with the larger reefs appeared to be favorable at Clancey. At many places in the Clancey and Free Enterprise areas gray cryptocrystalline silica is indicative of radioactivity.

\section{LITERATURE CITED}

Billingsley, P., 1916, The Boulder batholith of Montana : Am. Inst. Min. Eng. Trans. vol. 51, pp. 31-56.

Billingsley, P., and Grimes, J. A., 1918, Ore deposits of the Boulder batholith of Montana: Am. Inst. Min. Eng. Trans. vol. 58, pp. 284-332.

Knopf, Adolf, 1913, Ore deposits of the Helena mining region, Montana : U. S. Geol. Surrey Bull. 527.

Pardee, J. F., and Schrader, F. C., 1933, Metalliferous deposits of the greater Helena mining region, Montana: U. S. Geol. Surrey Bull. 842.

Ransome, F. L., 1921, Quicksilver, treatment of ores, uses, mineralogy, deposits of the world: Mineral Resources U. S., 1917, part 1-F, pp. 367-424.

Roberts, W. A., and Gude, A. J., 3d, 1953, Uranium-bearing deposits west of Clancey, Jefferson County, Mont. : U. S. Geol. Survey Bull. 988-F. 


\section{INDEX}

Acknowledgments.

Alaskite

Alteration $148,149,150,151,154$ $148-149,150,152-153$

Dacite

Dikes

148,150 $148,149,150$

History

143

Location 152-153

Mineralogy 147

Production

Prospecting 153-154

Quartz monzonite $148,149,150,151,153,154$
Radioactivity, anomalies_..................... 155 detection................................. 145, 154 intensity

Sedimentary rocks. . . .

Siliciflcation._._...................... 148, 150, 151, 154

Structure

Uranium minerals, autunite gummite-type ....................... 151, 152, 153 metatorbernite.......................... 152, 153 occurrence....................... 143, 145, 151, 152 origin .......................................... 143 production...........-. 147

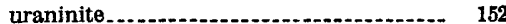
uranophane. zeunerite................................... 152 


